\title{
PERENCANAAN POLA KEMITRAAN DALAM PENINGKATAN KESEJAHTERAAN PETANI KPH XIII KAWASAN DOLOK SANGGUL KABUPATEN HUMBANG HASUNDUTAN
}

\author{
Sarintan Efratani Damanik ${ }^{1)}$ dan Sahata Purba ${ }^{2)}$ \\ ${ }^{1}$ Jurusan Kehutanan, Fakultas Pertanian, Universitas Simalungun \\ ${ }^{2}$ Peneliti KPH XIII Kabupaten Humbang Hasundutan \\ ${ }^{1} \mathrm{Jl}$. Sisisngamangaraja Barat Pematangsiantar 21137 \\ ${ }^{2} J 1$. Siliwangi Km 1 Dolok Sanggul 22457 \\ E-mail : damanikintan@yahoo.com ${ }^{1)}$, 13.doloksanggul@gmail.com²)
}

\begin{abstract}
ABSTRAK
Perencanaan pola kemitraan dalam peningkatan kesejahteraan petani di kawasan KPH XIII Dolok Sanggul Kabupaten Humbang Hasundutan.Tujuan penelitian adalah menganalisis pola kemitraan dalam peningkatan kesejahteraan petani Di Kawasan KPH XIII Dolok Sanggul Kabupaten Humbang Hasundutan. Metode penelitian adalah menggunakan penelitian kuantitatif analisis regresi linier berganda. Hasil penelitian diperoleh pola kemitraan dan peranan kelembagaan berpengaruh sebesar $71,3 \%$ dalam peningkatan kesejahteraan petani. Kesimpulan, pola kemitraan dan peran kelembagaan berengaruh positif terhadap peningkatan kesejahteraan petani. Model pola kemitraan yang dibutuhkan oleh masyarakat petani KPH XIII kawasan Dolok Sanggul adalah pola kemitraan pada lahan pemerintah, dan pelaksanaan proses serta pencapaian pemberdayaan dicapai dengan menciptakan kondisi dan suasana yang memungkinkan potensi masyarakat berkembang secara optimal. Penciptaan kondisi yang memungkinkan masyarakat KPH XIII untuk dapat berkembang lebih jauh dalam bidang ekonomi yaitu dengan menciptakan pemungkinan pemanfaatan potensi lokal dengan kegiatan ternak lebah madu dengan sistim agroforestry kopi dan jagung. Kesimpulan,untuk menunjang keberhasilan pembangunan hutan di KPH XIII harus berbasis kemitraan, perlu adanya keterlibatan berbagai pihak yang dilandasi oleh tujuan dan manfaat. Model pembangunan hutan dengan pola kemitraan PHBM (Pengelolaan Hutan Bersama Masyarakat), antara kelompok tani dengan KPH XIII yang tepat adalah model yang dibangun berdasar pada pengembangan dan penerapan tehnologi tepat guna
\end{abstract}

Kata kunci : peningkatan kesejahteraan, pola kemitraaan, kelompok tani, efisiens dan efektivitas

\section{PENDAHULUAN}

Pembangunan adalah suatu proses perubahan yang dilakukan melalui upaya-upaya secara sadar dan terencana. Di dalam pembangunan harus secara terencana lebih detail seperti yang dikemukan oleh Damanik (2019)), yaitu perencanaan adalah suatu proses berkelanjutan yang melibatkan keputusan dan pilihan, tentang cara-cara, alternatif menggunakan sumberdaya yang tersedia, dengan tujuan untuk mencapai tujuan tertentu pada beberapa waktu di masa depan.. Untuk mendukung pembangunan perlu adanya perencanaan hutan dengan tujuan mendayagunakan fungsi hutan dengan menciptakan kegiatan yang dapat mempengaruhi proses yang sedang berjalan (Rosmiyati, \& dkk. 2000), atau menciptakan proses baru, agar hutan memberikan sumbangan dengan semaksimal mungkin untuk meningkatkan kesejahteraan masyarakat.

Pengelolaan hutan di Indonesia sangat dipengaruhi oleh sistem pemerintahan (UUD No. 32 tahun 2004), dalam hal ini ditandai oleh terjadinya perpindahan kekuasaan politik dan pemerintahan dari sentralisasi menjadi desentralisasi banyaknya kelemahan dalam perencanaan, sehingga proses yang benar sangat diperlukan dalam perencanaan terutama dalam konteks otonomi daerah setelah pemberlakuan Undang-Undang Nomor 32 Tahun 2004.
Reformasi yang telah mendorong terjadinya perubahan mendasar atas paradigma dalam pengelolaan Kehutanan Indonesia (Niken, 2003). Perubahan tersebut diawali dengan bergesernya sistem pengelolaan hutan yang semula berbasis negara menuju pengelolaan hutan yang bertumpu pada sumber daya hutan yang berkelanjutan. Satu di antara implikasi perubahan sistem tersebut adalah diberlakukannya desentralisasi pengelolaan hutan kepada pemerintah daerah dan masyarakat luas (Butarbutar, 2007). Sektor kehutanan juga berkehendak mendorong desentralisasi tersebut. Namun tidaklah semudah yang dibayangkan banyak orang untuk melaksanakannya. Lahirnya PP No. 38/2007 tentang pembagian kewenangan pemerintah pusat, pemerintah daerah provinsi dan pemerintah daerah kabupaten/kota, urusan yang menjadi kewenangan daerah terdiri dari urusan wajib dan urusan pilihan. Urusan pemerintahan wajib adalah urusan pemerintahan yang wajib diselenggarakan oleh pemerintahan daerah yang terkait dengan pelayanan kebutuhan dasar bagi masyarakat seperti pendidikan dasar, kesehatan, lingkungan hidup, perhubungan, kependudukan dan sebagainya Sedangkan urusan pemerintahan yang bersifat pilihan adalah urusan yang secara nyata ada dan berpotensi untuk meningkatkan kesejahteraan masyarakat sesuai dengan kondisi (Sumodiningrat, 2001), kekhasan dan potensi 
unggulan daerah yang bersangkutan. mata pencaharian penduduk dan pemanfaatan lahan yang ada di daerah.

Permasalahan kehutanan saat ini sudah berkembang semakin kompleks. Permasalahan dan tantangan dalam mewujudkan kelestarian hutan dan kesejahteraan masyarakat sekaligus tidak bisa lagi hanya didekati dengan solusi yang bersifat teknis kehutanan saja. Saat ini, peta permasalahan kehutanan telah bergeser dari permasalahan yang bersifat teknis ke permasalahan ekonomi, sosial serta dampak kebijakan sektor kehutanan yang kian hari kian kompleks dan harus ditangani segera termasuk dalam perencanaan pengelolaannya (Niken, 2003).

Perencanaan dibuat untuk mencapai tujuan pada suatu organisasi. Perencanaan merupakan suatu kegiatan pendahuluan yang harus dilakukan, sebelum kegiatan pokok dilaksanakan. Perencanaan diperlukan karena adanya keterbatasan sumber daya dan sumber dana yang tersedia sehingga tidak menyulitkan dalam menentukan suatu pilihan kegiatan (Damanik, 2019). Perencanaan pembangunan dapat diartikan sebagai suatu proses perumusan alternatif-alternatif atau keputusan-keputusan yang didasarkan pada data-data dan fakta-fakta yang akan digunakan sebagai bahan untuk pelaksanakan suatu rangkaian kegiatan atau aktifitas kemasyarakatan, baik yang bersifat fisik yaitu material maupun non fisik mental dan spiritual, dalam rangka mencapai tujuan yang lebih baik (Leeuwis, 2010). Sedangkan perencanaan pembangunan daerah adalah suatu proses penyusunan tahapan-tahapan kegiatan yang melibatkan berbagai unsur di dalamnya, guna pemanfaatan dan pengalokasian sumber daya yang ada dalam rangka meningkatkan kesejahteraan sosial dalam suatu lingkungan wilayah atau daerah dalam jangka waktu tertentu (Edoho, 2015).

Hutan yang hanya diorentasikan kepada pemanfaatan hutan melalui pemberian izin semata dengan cara membagi-bagi seluruh kawasan hutan produksi. Tata kelola harus dilihat dari proses keserasian antara pengukuhan dan penetapan kawasan hutan dengan Rencana Tata Ruang Wilayah Provinsi, sehingga pengelolaan hutan dilihat sebagai sebuah landscape ekonomi, politik, sosial dan tata ruang yang utuh (Anantanyu, 2011).

Permasalahan konversi hutan ini berakar dari pertambahan penduduk yang terus meningkat setiap tahun. Pertambahan penduduk selalu menuntut akan tercukupinya kebutuhan pangan, kebutuhan kayu bakar, kebutuhan kayu pertukangan, dan tempat pemukiman masyarakat. Di lain pihak lahan pertanian sebagai penghasil pangan luasannya terbatas, sehingga alternatif utama untuk pemenuhan kebutuhan pangan adalah mengkonversi lahan hutan menjadi lahan pertanian (Simon, 2001).

Keterbatasan lahan yang dimiliki oleh masyarakat di sekitar hutan akan berakibat pada kondisi hutan di sekelilingnya. Masyarakat akan selalu menggantungkan hidupnya pada hutan yang ada di sekeliling pemukimannya untuk memenuhi kebutuhan hidup yang terus menerus akan meningkat (Vivek, 2011). Tanpa pengelolaan yang tepat, hal seperti ini merupakan ancaman bagi keberadaan dan kelestarian hutan, serta dapat menurunkan fungsi dari peruntukan hutan tersebut. Sejalan dengan waktu, hutan yang semula dianggap tidak akan habis berangsur-angsur mulai berkurang (Ansori, 2012). Banyak lahan hutan digunakan untuk kepentingan lain, seperti pertanian, luas kawasan hutan yang telah beralih fungsi menjadi lahan pertanian dan pemukiman (Afri, 2008).

Dinamika pembangunan nasional dalam peningkatan kesejahteraan masyarakat yang telah menimbulkan tuntutan untuk mewujudkan kualitas kehidupan yang lebih baik. Aspirasi dan tuntutan masyarakat itu dilandasi oleh hasrat untuk lebih berperan serta dalam mewujudkan masyarakat yang maju, mandiri dan sejahtera (Kuncoro, 2004). Pencapaian hal tersebut dapat terwujud apabila pembangunan berjalan secara optimal, serta terkoordinasi dengan baik mulai dari tingkat petani, organisasi kelompok tani, tingkat pemerintah desa, kecamatan, kabupaten/kota, provinsi dan tingkat pusat (Sumodiningrat, 2001). Masing-masing tingkatan ini mempunyai peranan, tugas dan fungsi tertentu sesuai dengan kedudukannya. Kesinambungan pembangunan merupakan syarat mutlak untuk memperoleh hasil yang optimal menuju masyarakat adil, makmur dan sejahtera (Butarbutar, 2007).

Kemitraan adalah suatu strategi bisnis yang dilakukan oleh dua pihak atau lebih dalam jangka waktu tertentu untuk meraih keuntungan bersama dengan prinsip saling membutuhkan dalam mewujudkan sinergi dalam pengelolaan hutan (Afri, 2008)

Pola kemitraan atau kerjasama merupakan hal baru dalam pengelolaan hutan. Kemitraan dapat meningkatkan partisipasi masyarakat dalam mengelola hutan dan mencegah terjadinya konflik. Kemitraan dilakukan berdasarkan kesepakatan antara pemegang izin pemanfaatan hutan atau pemegang hak pengelolaan dengan masyarakat setempat. Pada sat ini, peranan kelompok tani semakin luas, kegiatan tidak hanya terbatas pada kegiatan bertani, tetapi melingkupi kegiatan lain yang mengarah pada kegiatan ekonomi (Ansori, 2012)..

Dalam pengusahaan hutan ini diharapkan memberikan manfat yang dapat diterima oleh masyarakat berupa bagian dari keutungan pengusahaan dan keterlibatan mereka dalam pengelolaan hutan. Pengusahaan hutan berbasis kemitraan tidak hanya menyangkut managerial yang berkaitan dengan faktor sosial, ekonomi dan budaya masyarakat setempat (Bragg, 2017). Oleh karena itu untuk menunjang keberhasilan pembnagunan hutan berbasis kemitraan perlu adanya keterlibatan berbagai pihak yang dilandasi oleh tujuan memperoleh manfaat (Coillte, 2014)

Mendorong dan membibimbing petani agar mampu bekerjasama di bidang ekonomi ecara kelompok yang dapat meningkatkan jumlah pendapatan. Menumbuh kembangkan kelompok tani melalui peningkatan akses permodalan bagi petani, pembinaan kepada organisasi kelompok, serta peningkatan efisiensi serta efektivitas usahatani rakyat. Meningkatkan kapasitas SDM petani melalui berbagai kegiatan pendampingan, dan pelatihan yang dirancang secara khsusus bagi pengurus dan anggota kelompok tani. Peranan 
dan fungsi kelompok tani dapat ditingkatkan dengan menumbuhkembangkan kekuatan-kekuatan yang dimiliki, menggerakan dan mendorong perilaku anggotanya ke arah pencapaian tujuan dan kesejahteraan kelompok (Niken. 2003).

Kemitraan mampu menjadi alternatif penyelesaian konflik antara pemegang izin dan masyarakat. Kemitraan kehutanan ini juga sebagai upaya untuk mengatasi masalah degradasi, deforestasi dan perambahan. Hal ini sesuai dengan Peraturan Menteri Kehutanan Republik Indonesia Nomor : P.39/Menhut-II/2013 Pasal 6 (1) yang menyatakan bahwa Pengelola Hutan, Pemegang Izin dan $\mathrm{KPH}$ wajib memberdayakan masyarakat setempat yang terdapat di sekitarnya melalui kemitraan kehutanan.

Kemitraan biasanya terjalin antara pihak-pihak yang bermitra apabila adanya kesamaan kepentingan, kebutuhan, saling memperkuat atau saling menguntungkan. Akan tetapi dapat pula timbul karena adanya faktor lain seperti faktor dorongan pembinaan. Kemitraan dapat pula sebagai model pemberdayaan kelompok untuk lebih meningkatkan kemampuan untuk mencapai target yang dicita-citakan (Ansori, 2012).

Pola kemitraan untuk pengembangan usaha wanatani memiliki tujuan yang khas, dimana output yang sangat diharapkan tidak hanya bernilai ekonomis. Menurut Leeuwis (2010), pola kemitraan masyarakat dengan mempertimbangkan (1). Kesesuaian usaha yang akan dilaksanakan, (2). Saling menguntungkan dalam peningkatan ekonomi, (3). Hubungan secara sukarela, dan (4)Kesetaraan sesama anggota, (5). Pembinaan masyarakat. Selain fungsi ekonomi sebagai salah satu tujuan utama dari pola kemitraan dan fungsi lembaga juga perlu didukung oleh agroforestry dan partisipasi masyarakat (Damanik, 2019). Agroforestry berperan dalam pelestarian sumberdaya genetik tanaman, habitat satwa, konservasi tanah dan air dan menjaga kesetimbangan biodiversity. Kunci utama keberhasilan agroforestry adalah pemilihan jenis dan kombinasi yang tepat, yang disesuaikan dengan kondisi dan sosial ekonomi masyarakat setempat (Vivek, 2011).

Pola kemitraan dalam pengelolaan usahatani adalah pola hubungan antara petani, kelompok tani. Menurut Anantanyu (2011), pola kemitraan dapat dilihat berdasarkan 5 pola, yaitu: 1) pola inti-plasma, yakni perusahaan bertindak dalam menyediakan lahan, sarana produksi, bimbingan teknis, manajemen, menampung dan mengolah, serta memasarkan hasil produksi); 2) pola subkontrak, yakni pola kemitraan antara kelompok mitra usaha dengan perusahaan mitra usaha yang memproduksi komponen yang diperlukan perusahaan mitra sebagai bagian dari produksinya; 3) pola dagang umum, yakni hubungan usaha dalam pemasaran hasil produksi; 4) pola keagenan, yakni di antara pihak-pihak yang bermitra terdapat kesepakatan tentang target-target yang harus dicapai dan besarnya komisi yang diterima oleh pihak yang memasarkan produk; dan 5) pola kerjasama operasional agribisnis, yakni kelompok mitra menyediakan sarana produksi seperti lahan, sarana, dan tenaga kerja, sedangkan perusahaan hanya menyediakan modal, biaya, manajemen, (Tambunan, 2003), dan pengadaan sarana produksi untuk mengusahakan atau membudidayakan suatu komoditas pertanian,

Pemberdayaan berarti mempersiapkan masyarakat desa untuk untuk memperkuatdiri dan kelompok mereka dalam berbagai hal, mulai dari soal kelembagaan dan kepemimpinan, sosial ekonomi, dan politik dengan mengmenggunakan basis kebudayaan mereka sendiri. Menurut Damanik (2019), prinsip dari proses pemberdayaan yang harus dipedomani yaitu menciptakan ruang atau masyarakat memiliki kemampuan untuk memanfaatkan ruang atau peluang yang tercipta, dan dalam kondisi tertentu membuat seorang individu atau sekelompok manusia yang telah mencapai kondisi itu tidak lagi tergantung pada bantuan dari pihak ketiga untuk mengamankan kepentingan individu atau kelompok.

Sebagai inti membina dan mengembangkan usaha kecil yang menjadi plasmanya dalam menyediakan lahan, penyediaan sarana produksi, pemberian bimbingan teknis manajemen usaha dan produksi, perolehan, penguasaan dan peningkatan teknologi yang diperlukan bagi peningkatan efisiensi dan produktivitas usaha. Menurut penjelasan Pasal 27 huruf (b) Undang-Undang Nomor. 9 Tahun 1995 bahwa: Pola subkontrak adalah hubungan kemitraan antara Usaha Kecil dengan Usaha Menengah atau Usaha Besar, yang di dalamnya Usaha Kecil memproduksi komponen yang diperlukan oleh Usaha Menengah atau Usaha Besar sebagai bagian dari produksinya. Dapat pula dikatakan bahwa dalam pola subkontrak, usaha kecil memproduksi barang dan atau jasa yang merupakan komponen atau bagian produksi usaha menengah atau usaha besar. Menurut penjelasan Pasal 27 huruf (c) Undang-Undang Nomor. 9 Tahun 1995, Pola Dagang Umum adalah: Hubungan kemitraan antara Usaha Kecil dengan Usaha Menengah atau Usaha Besar, yang di dalamnya Usaha Menengah atau Usaha Besar memasarkan hasil produksi Usaha Kecil atau Usaha Kecil memasok kebutuhan yang diperlukan oleh Usaha Menengah atau Usaha Besar mitranya. Dalam pola waralaba pemberi waralaba memberikan hak untuk menggunakan hak atas kekayaan intelektual atau penemuan atau ciri usaha kepada penerima waralaba. Dengan demikian, maka dengan pola waralaba ini usaha menengah dan atau usaha besar yang bertindak sebagai pemberi waralaba menyediakan penjaminan dan atau menjadi penjamin kredit yang diajukan oleh usaha kecil sebagai penerima waralaba kepada pihak ketiga. Berdasarkan penjelasan Pasal 27 huruf (e) Undang-Undang Nomor. 9 Tahun 1995, pola keagenan adalah hubungan kemitraan, yang di dalamnya Usaha Kecil diberi hak khusus untuk memasarkan barang dan jasa Usaha Menengah atau Usaha Besar mitranya. Dalam pola keagenan, usaha menengah dan atau usaha besar dalam memasarkan barang dan jasa produknya memberi hak keagenan hanya kepada usaha kecil. Dalam hal ini usaha menengah atau usaha besar memberikan keagenan barang dan jasa lainnya kepada usaha kecil yang mampu melaksanakannya.

Pendapatan rumah tangga petani dapat mencerminkan keadaan ekonomi rumah tangga. Tinggi rendahnya tingkat 
pendapatan rumah tangga petani dapat memperlihatkan tingkat kesejahteraan suatu rumah tangga (Afri, 2008). Secara agregat pendapatan rumah tangga petani agroforestri di $\mathrm{HKm}$ diperoleh dari dua sumber pendapatan, yaitu sumber pendapatan dari pertanian dan non-pertanian. Sumber pendapatan pertanian terdiri dari usaha tani agroforestri yang merupakan sumber pendapatan pokok dan berburuh tani, sedangkan sumber pendapatan dari non-pertanian terdiri dari buruh nonpertanian, usaha mesin giling kopi. Pendapatan dari sektor pertanian dengan sistem agroforestri pada lahan kawasan KPH sangat membantu dalam meningkatkan ekonomi rumah tangga masyarakat. Proporsi pendapatan dari lahan kawasan pada masing-masing kelompok pengelolaan lahan dari yang sempit ke yang semakin luas. Mata pencaharian pokok masyarakat adalah petani (Filson, 2009)

Kelompok merupakan suatu unit sosial yang terdiri dari sejumlah individu yang satu dengan individu lainnya, mempunyai hubungan saling tergantung sesuai dengan status dan perannya, mempunyai norma yang mengatur tingkah laku anggota kelompok itu. Kelompok pada dasarnya adalah gabungan dua orang atau lebih yang berinteraksi untuk mencapai tujuan bersama, dimana interaksi yang terjadi bersifat relatif tetap dan mempunyai struktur tertentu (Rosmiyati, 2000.)

Kelembagaan umumnya banyak dibahas dalam sosiologi, antropologi, hukum dan politik, organisasi dan manajemen, psikologi maupun ilmu lingkungan yang kemudian berkembang ke dalam ilmu ekonomi karena kini mulai banyak ekonom yang berkesimpulan bahwa dalam kegagalan pembangunan ekonomi pada umumnya karena kegagalan dari pihak kelembagaan (Wahyudi, 2016). Dalam bidang sosiologi dan antropologi kelembagaan banyak ditekankan pada norma, tingkah laku dan adat istiadat dalam upaya meningkatkan daya saing petani salah satunya adalah pengembangan kelembagaan pertanian, pemberdayaan, pemantapan dan peningkatan kemampuan kelompok petani kecil (Filson, 2009)

Dalam rangka pemberdayaan petani sebagai salah satu pelaku agribisnis hortikultura, maka perlu menumbuh kembangkan kelompok tani yang mandiri dan berwawasan agribisnis. Dengan memperhatikan prinsipprinsip kemitraan adanya pelaku kemitraan petani, kelompok tani, pengusaha, dan pemerintah saling menguntungkan (Leeuwis. 2010)

Peran pemerintah sangat dibutuhkan untuk mengatasi gangguan yang mengancam keberadaan hutan. Salah satu cara pemerintah adalah dengan mengeluarkan kebijakan pembangunan Kesatuan Pengelolaan Hutan (KPH) yang merupakan program prioritas pemerintah dalam rangka memperbaiki tata kelola hutan dan memperkuat desentralisasi sektor kehutanan mengalami degradasi dan deforestasi. Kawasan KPH telah mengalami perambahan oleh masyarakat dan kawasan hutan dialih fungsikan menjadi lahan perkebunan kopi (Oravska, 2012).
Sebagai suatu lembaga sosialdi desa, Kelompok Tani merupakan lembaga yang sampai saat ini mengakar cukup kuat dimasyarakat, baik hubungan dengan pemerintah dan sesama anggota Kelompok Tani. Peran ganda yang disandang pemeritah yaitu meningkatkan kesejahteraan masyarakat, hal tersebut menyebabakan kelompok tani sebagai salah satu elemen yang cukup penting dalam pembangunan bangsa. Kondisi hutan Indonesia saat ini sangat memprihatinkan dengan berkurangnya luas tutupan lahan hutan dan tingginya laju deforestasi. Perubahan tutupan hutan ini disebabkan oleh berbagai faktor salah satunya aktivitas manusia berupa penguasaan lahan dan penyerobotan kawasan hutan penguasaan lahan yang dilakukan oleh manusia merupakan ancaman yang serius bagi keberadaan hutan (Ansori, 2012).

Permen RI (2011), telah mencatat berbagai gangguan yang mengancam eksistensi dan kondisi kawasan hutan, sedangkan gangguan terhadap tegakan hutan berupa penebangan ilegal diperkirakan telah mengakibatkan kehilangan antara lain kayu olahan/bulat dan satwa liar.

Penting dalam menggerakan upaya pembangunan pertanian (Edoho, 2015). Penguatan kelembagaan sangat perlu dilakukan melalui beberapa upaya, antara lain mendorong dan membimbing petani agar mampu bekerjasama di bidang ekonomi secara berkelompok, menumbuhkkembangkan kelompok tani melalui peningkatan fasilitas bantuan dan akses permodalan dan peningkatan efisiensi dan efektivitas petani, serta meingkatkan kapasitas sumber daya manusia petani melalui berbagai pendampingan, dan pelatihan untuk pengurus dan anggota (Permatasari, 2003).

Upaya untuk peningkatan kesejahteraan kelompok tani dalam pemberdayaan dilakukan oleh penyuluh pertanian lapangan. Meskipun demikian pendampingan pembinaan kelompok tani juga bisa dilakukan oleh LSM dan organisasi lainnya yang dianggap mampu untuk dilibatkan dalam usaha penguatan kelompok tani dalam pemberdayaan masyarakat. Pembentukan dan penumbuhan suatu kelompok tani mestilah ditempatkan kedalam konteks yang lebih luas,yaitu kedalam konteks pengembangan ekonomi dan kemandirian masayarakat yang menuju pembangunan yang berkelanjutan (Budimanta, 2004).

Pembangunan pertanian pada dasarnya ditujukan bagi peningkatan kesejahteraan masyarakat terutama petani. Untuk itu dalam setiap tahapan kegiatan pembangunan pertanian kesejahteraan petani selalu menjadi tujuan dan sejalan dengan konsep bidang kehutanan.Pengelolaan hutan dalam konsep KPH harus dilakukan sehingga hutan lestari dan masyarakat sejahtera dapat terwujud. Pengelolaan hutan lestari menjadi tujuan utama pembangunan KPH, karena hutan yang lestari diharapkan dapat memberikan manfaat bagi para pihak yang berkepentingan dengan sektor kehutanan (Damanik, 2019).

Dalam konsep KPH, diharapkan menjadi dasar dalam terlaksananya sistem pengelolaan hutan yang lestari dan berkeadilan dan berkesinambungan. Sistem pengelolaan yang menjadi peran manajerial sehingga diharapkan meningkatkan transparansi dan akuntabilitas tatakelola hutan dan menjamin kepastian usaha dan juga keadilan bagi masyarakat. Konsep $\mathrm{KPH}$ saat ini merupakan sebuah arah proses desentralisasi dan 
pendelegasian wewenang yang ditandai dengan pembagian yang jelas antara fungsi kewenangan urusan pemerintahan dan kegiatan operasional pengelolaan hutan (Butarbutar, 2007).

Dalam perkembangannya, KPH sangat banyak mengalami tantangan dan hambatan, terutama dari daerah akibat desentralisasi otonomi daerah. Dalam skema pembangunan daerah, pembangunan dibidang kehutanan masih dikategorikan sebagai program pilihan lain bukan program utama, hal ini tidak mengharuskan daerah menjadikan pembangunan KPH menjadi prioritas utama. Dengan kurangnya dukungan maka timbul keragu-raguan daerah dalam pembangunan KPH ini mengakibatkan terhambatnya pelaksanaan pembangunan dan program $\mathrm{KPH}$.

Pembentukan KPH ditujukan untuk menyediakan wadah bagi terselenggaranya kegiatan pengelolaan hutan secara efisien dan lestari. Implementasi pembangunan KPH banyak menghadapi permasalahan baik dari sisi kelembagaan dan sosial. Permasalahan yang ada dari sisi kelembagaan meliputi hambatan dari pemangku kepentingannya sendiri, dalam peraturan perundangan, organisasi, pendanaan, dan SDM. Permasalahan dari sisi sosial lebih cenderung kepada klaim lahan oleh masyarakat dan perbedaan jenis tanaman yang akan dikembangkan pada areal KPH. Faktor-faktor yang mempengaruhi proses pembentukan organisasi KPH adalah faktor ko munikasi, sumber daya dan birokrasi.

Pembangunan KPH masih memerlukan reforma regulasi yang harus didukung oleh berbagai unsur kepentingan, baik pemerintah pusat, pemerintah daerah, pihak ketiga maupun masyarakat adat lokal.

Pemerintah Daerah Kabupaten Humbang Hasundutan tidak dapat dipisahkan dari kegiatan penyelenggaraan dan mengakomodir aspirasi masyarakat yang terus berkembang serta dalam menghadapi perubahan yang terjadi baik dalam lingkungan maupun nasional yang secara langsung akan berpengaruh pada roda pemerintahan dan pelaksanaan program pembangunan. Pemerintahan harus benar-benar siap dan mampu untuk mengelola setiap potensi yang ada dalam lingkungan masyarakat untuk dapat mewujudkan kesejahteraan bagi rakyatnya. Terutama peranan suatu kelembagaaan pemerintah dan pola kemitraan dibidang kehutanan. Kesatuan Pengelolaan Hutan (KPH) XIII Dolok Sanggul memiliki Kelompok Tani Binaan. Kelompok Tani Binaan saat ini sebanyak 15 Kelompok Tani. Saat ini potret peranan kelembagaan dan pola kemitraan serta peningkatan kesejahteraan petani di KPH XIII diakui masih belum sebagaimana yang diharapkan.

Pada saat ini kondisi sebagian besar kelompok tani di KPH XIII Kabupaten Humbang Hasundutan dari tahun ketahun dapat dikatakan belum mengalami suatu perkembangan seperti yang diharapkan atau hanya berjalan di tempat bahkan sampai menurun. Gambaran dari kelompok tani tersebut didalam kegiatanya rendah dan sebagian kelompok tani disini sudah bubar tetapi masih terdaftar. Rendahnya kinerja didalam kelompok tani disebabkan oleh kurangnya keinginan masyarakat dan kurangnya peran pengurus, anggota kelompok yang kurang jelas, struktur organisasi yang kurang lengkap dan tidak berfungsi sehingga produktivitas usaha tani rendah yang mengakibatkan peningkatan ekonomi sangat rendah.

Melihat potensi ekonomi yang besar dari budidaya lebah madu bagi peningkatan pendapatan masyarakat sekitar hutan di kawasan hutan perlu sekali untuk dilaksanakan. Potensi ini berpeluang untuk menekan angka kemiskinan yang terjadi di kawasan, perlu secara terus menerus dalam upaya mendorong masyarakat desa penyangga untuk mengembangkan usaha ekonomi produktif (Supriyati, dkk., 2000). Upaya tersebut selain untuk meningkatkan kemauan dari masyarakat itu sendiri mengembangkan perekonomian desa juga sebagai strategi untuk mengurangi aktivitas masyarakat dalam kawasan konservasi yang cenderung menurunkan kualitas dan fungsi kawasan (Sarintan, 2019).

Potensi desa dengan kondisi kemiskinan, perlu merumuskan strategi pemberdayaan masyarakat melalui pengembangan budidaya lebah madu dalam upaya penanggulangan kemiskinan pada Kelompok Tani di sekitar KPH (Butarbutar, 2007). Pelaksanaan proses dan pencapaian pemberdayaan dicapai dengan menciptakan kondisi dan suasana yang memungkinkan potensi masyarakat berkembang secara optimal. Penciptaan kondisi yang memungkinkan masyarakat untuk dapat berkembang lebih jauh dalam bidang ekonomi yaitu dengan menciptakan pemungkinan pemanfaatan potensi lokal yang ada di KPH. Penguatan dalam alam meningkatkan ilmu pengetahuan serta kemampuan terutama berkaitan dengan potensi lokal sosial sehingga masyarakat mampu untuk memecahkan masalah serta dapat berguna dalam memenuhi kebutuhan dasar hidupnya (Leeuwis, 2010). Penguatan yang berupa capaian hasil yang telah diperoleh, dalam proses pemberdayaan lebah madu. Perlindungan yaitu melindungi masyarakat dalam proses pemberdayaan lebah madu, perlindungan ini menjaga agar tahapan penguatan pemberdayaan yang telah dilakukan tidak mengalami kegagalan. Pemeliharaan situasi yang kondusif dan selalu terjaga dengan tujuan untuk menjaga keseimbangan peran (Tambunan, 2003).

Di kalangan petani dipandang menjadi instrumen untuk transformasi dan meningkatkan produktivitas di sektor pertanian. Untuk beberapa dekade, pola kemitraan telah mempunyai peran yang luar biasa dalam rangka mewujudkan pertumbuhan dan perkembangan ekonomi nasional. Walaupun kerjasama antar petani dapat meningkatkan pembangunan pertanian, namun perlu adanya intervensi dari pemerintah berupa regulasi dan program-program untuk meningkatkan kemampuan petani.

Sektor kehutanan merupakan salah satu sektor yng diutamakan di Kabupaten Humbang Hasundutan. Sektor kehutanan ini dikelola oleh KPH XIII Dolok Sanggul yang menerapkan kesejahteraan pada masyarakat sekitar hutan. Selain mensejahterakan masyarakat sekitar kawasan hutan, pihak KPH XIII juga mempunyai peranan penting dalam kelestarian hutan yang ada di KPH XIII

Program-program yang dilakukan oleh pihak KPH XIII tentunya bertujuan untuk meningkatkan kesejahteraan 
masyarakat serta bertujuan untuk meningkatkan kelestarian kawasan hutan. Program-program tersebut pada intinya adalah untuk menjalin kerjasama antara pihak KPH dengan masyarakat. Hutan yang dipegang oleh pihak KPH XIII Dolok Sanggul sebagian besar ditanami pohon kopi dimana pohon kopi tersebut mempunyai nilai ekonomi yang cukup tinggi. Untuk menanggulangi agar kerusakan hutan yang terjadi di Kabupaten Humbang Hasundutan tidak terlalu parah, pihak KPH XIII menerapkan kebijakan yang melibatkan masyarakat langsung. Hal ini dimaksudkan agar masyarakat mempunyai peranan dan tanggung jawab langsung dalam pengelolaan hutan guna melestarikan kelestarian hutan. Kebijakan pengelolaan hutan yang melibatkan msyarakat langsung ini disebut dengan sebutan Pengelolaan Hutan Bersama Masyarakat (PHBM).

Permasalahan dalam konversi hutan ini berasak dari pertambahan jumlah penduduk yang terus menerus akan meningkat. Pertambahan jumlah penduduk akan menuntut tercukupinya kebutuhan pangan, kebutuhan kayu bakar, kebutuhan kayu pertukangan, dan tempat pemukiman yang layak. Di lain pihak lahan pertanian sebagai penghasil pangan luasannya semakin terbatas, sehingga alternatif utama dalam pemenuhan kebutuhan pangan adalah dengan mengkonversi lahan hutan menjadi lahan pertanian (Simon, 2001). Keterbatasan lahan yang dimiliki oleh masyarakat di sekitar hutan akan berakibat pada kondisi hutan di sekelilingnya. Masyarakat yang tani akan menggantungkan hidupnya pada lahan hutan yang ada di sekeliling pemukimannya guna memenuhi kebutuhan hidup yang terus meningkat. Tanpa pengelolaan yang tepat, hal seperti ini merupakan ancaman bagi keberadaan dan kelestarian hutan, serta dapat menurunkan fungsi dari peruntukan hutan tersebut.

Pada waktu lampau, pengelolaan hutan menekankan pada pendekatan teknik dan ekonomi. Namun sekarang rimbawan dituntut untuk menfokuskan masalah sosial sebagai bagian dari proses pengelolaan hutan yang lestari. Memecahkan masalah sosial memerlukan sebuah pemahaman terhadap nilai-nilai yang dipegang oleh masyarakat dan partisipasi dari kelompok masyarakat kunci dalam membuat keputusan tentang pengelolaan hutan. Sekarang ini kunci keberhasilan dari pengelolaan sumber daya hutan ditentukan oleh keberhasilannya dalam memecahkan masalah sosial ekonomi masyarakat. Gagal dalam pemecahan masalah ekonomi masyarakat, akan gagal pula dalam upaya pengelolaan hutan

Sejalan dengan paradigma baru pembangunan kehutanan yang mengarah pada terwujudnya kelestarian hutan sebagai sistem penyangga kehidupan, memperkuat ekonomi rakyat, mendukung perekonomian nasional bagi kesejahteraan rakyat, serta meningkatkan partisipasi masyarakat dalam pembangunan kehutanan, maka kebijakan pengelolaan dan pemanfaatan hutan haruslah betul-betul melibatkan dan menyentuh langsung masyarakat, khususnya masyarakat yang tinggal di sekitar hutan
Kondisi sosial ekonomi petani mempengaruhi produktivitas petani. Penelitian Usman (2013) menemukan bahwa adanya kemitraan antara koperasi dan petani sangat efektif meningkatkan pendapatan kelompok tani. Pola kemitraan tersebut dapat dipilih berdasarkan jenis permasalahan yang dihadapi oleh petani.

Pengelolaan hutan melalui skema kemitraan, baik bagi pemegang izin usaha pemanfaatan KPH dapat bermitra dengan masyarakat yang hidupnya dari hasil hutan dan lahan hutan. Skema kemitraan kehutanan digagas sebagai upaya untuk memberdayakan masyarakat di dalam dan sekitar hutan. Skema ini juga sebagai wahana penyelesaian konflik atas sumber daya hutan yang terjadi antara pengelola hutan dan unit manajemen hutan dengan masyarakat yang sudah memanfaatkan kawasan hutan. Pemberdayaan masyarakat setempat melalui kemitraan kehutanan dengan tujuan untuk meningkatkan kemampuan serta kemandirian masyarakat untuk mendapatkan manfaat sumber daya hutan dan menggunakannya secara optimal dan adil melalui kemitraan kehutanan dalam rangka peningkatan kesejahteraan masyarakat setempat

Kemitraan kehutanan antara pengelola hutan dengan masyarakat diharapkan menjadi solusi yang tepat dalam pengelolaan hutan. Kemitraan kehutanan antara KPH dengan kelompok tani binaan penting dilakukan untuk mengetahui perencanan pola kemitraan yang tepat antara KPH XIII dengan kelompok tani.

\section{RUANG LINGKUP}

Kemitraan yang dijalin antara KPH XIII dengan masyarakat diharapkan dapat meningkatkan pendapatan kelompok tani binaan, namun pada prakteknya beberapa petani yang mengeluhkan kecilnya pendapatan mereka dan permasalahan utama yang dihadapi kelompok tani binaan saat ini menyangkut tentang kurangnya permodalan. Dari informasi yang diperoleh, disebutkan bahwa pola kemitraan yang ada pada saat ini dilakukan oleh pihak KPH dengan kelompok tani usaha tani masih stagnan dan kurang memiliki dampak ekonomi bagi kelompok tani.

Perencanaan pola kemitraan adalah pola yang akan diterapkan untuk menjalinan kerjasama usaha yang saling menguntungkan antara kelompok tani dengan KPH XIII disertai dengan pembinaan dan pengembangan oleh sehingga saling memperkuat, memerlukan dan menguntungkan. Peningkatan kesejahteraan petani.

Jika kesejahteraan petani dapat ditingkatkan maka akan berdampak pula pada kesejahteraan dan peningkatan gizi masyarakat khususnya keluarga petani yang berada di sekitar kawasan KPH XIII dalam memenuhi kebutuhan keluarganya sehari-hari

Hasil yang diharapkan dari perencanaan pola kemitraan dalam peningkatan kesejahtreraan petani adalah dapat meningkatkan pendapatan kelompok tani binaan, menambah pengetahuan bagi para petani dan memberikan jaminan pasar yang pasti, kepastian pasar melalui kemitraan antara petani dengan KPH XIII sangat penting untuk memperoleh kepastian harga, kualitas dan kuantitas produk yang diinginkan. 


\section{BAHAN DAN METODE}

Berikut disajikan bahan dan metodologi dalam penelitian ini.

\subsection{Pola kemitraan}

Pola kerjasama yakni kelompok mitra menyediakan sarana produksi seperti lahan, sarana, dan tenaga kerja, sedangkan $\mathrm{KPH}$ hanya menyediakan modal, biaya, manajemen, dan pengadaan sarana produksi untuk mengusahakan atau membudidayakan suatu komoditas pertanian untuk peningkatan kesejahteraan

\subsection{Populasi dan sampel}

Keseluruhan jumlah anggota kelompok tani yang dibina oleh KPH XIII di Kabupaten Humbang Hasundutan. Jumlah anggota kelompok tani sebanyak 350 orang. Untuk sampel penelitian dipilih secara acak untuk dan sampel diambil sebanyak sebanyak 150 orang. Data yang telah terkumpul selanjutnya akan dianalisis dengan menggunakan analysis of variance (ANOVA).

\section{PEMBAHASAN}

Perencanaan kehutanan di daerah tidak bisa lepas dari perencanaan yang ada di tingkat pusat. Proses penyusunannya disusun secara berjenjang mulai dari tingkat pusat, provinsi, kabupaten, sampai unit terkecil. Semua tingkatan harus sinkron. Perencanaan pada level bawah harus mengacu dan mendukung perencanaan yang ada di bawah. Namun demikian untuk mengoptimalkan sudah barang tentu pada proses perencanaan di daerah harus disesuaikan dengan kondisi dan karakteristik lokal. Proses penyusunannnya juga harus melibatkan stakeholder yang ada di tingkat lokal.

\subsection{Peran kelembagaan dan pola kemitraan}

Kelembagaan adalah alat seseorang untuk mempunyai kepercayaan diri. Kelembagaan dan pola kemitraan akan lebih mudah di dalam menetapkan perencanaan dan prioritas pembangunan dengan mengorganisir individuindividu (masyarakat) ke dalam suatu lembaga-lembaga lokal yang mewakili aspirasi dari semua tingkatan dan membawa misi lembaganya.

Tabel 1. Anova Peranan Kelembagaan dan Pola Kemitraan

\begin{tabular}{|c|c|c|c|c|c|}
\hline Model & $\begin{array}{l}\text { Sum of } \\
\text { Squares }\end{array}$ & df & $\begin{array}{l}\text { Mean } \\
\text { Square }\end{array}$ & $\mathrm{F}$ & Sig. \\
\hline 1 Regression & 84,775 & 2 & 42,387 & 80,640 & ,000 \\
\hline Residual & 34,166 & 65 &, 526 & & \\
\hline Total & 118,941 & 67 & & & \\
\hline
\end{tabular}

Diperoleh nilai Fhitung 80,640 lebih besar dibandingkan dengan Ftabel 3,20 atau nilai sig 0,000 lebih kecil dari alpha 0,05 . Berdasarkan hasil yang diperoleh maka Ho ditolak dan H1 diterima.

Tabel 2. Pola Kemitraan dan Peranan Kelembagaan

\begin{tabular}{|l|c|c|c|}
\hline \multirow{2}{*}{ Model } & \multicolumn{2}{|c|}{$\begin{array}{c}\text { Unstandardized } \\
\text { Coefficients }\end{array}$} & \multirow{2}{*}{$\begin{array}{c}\text { Standardized } \\
\text { Coefficients }\end{array}$} \\
\cline { 2 - 3 } & B & Std. Error & \\
\hline (Constant) &, 953 &, 917 & \\
\hline Peranan Kelembagaan &, 366 &, 057 &, 438 \\
\hline Pola Kemitraan &, 572 &, 063 &, 625 \\
\hline
\end{tabular}

Dari hasil analisis regresi linier berganda koefisien determinasi diperoleh sebesar 0,953 , maka model regresi hasil penelitian adalah $\hat{\mathrm{Y}}=0,953+0,366 \mathrm{X}_{1}+0,572 \mathrm{X}_{2}$ nilai koefisien determinasi diperoleh adalah sebesar 0,713 , artinya bahwa peran lembaga dan pola kemitraan berpengaruh positif sebesar 71,3\% terhadap peningkatan kesejahteraan petani.

Kelembagaan petani yang kuat akan mampu memberi kemudahan bagi petani sekaligus melindungi petani dan praktek pemasaran yang tidak adil. Dengan demikian, proses revitalisasi kelembagaan petani menuju lembaga usaha harus memberi jaminan bagi proses alih-fungsi lahan karena untuk memenuhi kebutuhan petani akan uang tunai dapat dilakukan dengan meminjam dari lembaga koperasi tersebut tanpa harus menjual lahannya. Namun apabila seorang petani terpaksa harus menjualnya kembali kepada petani yang memiliki lahan di sebelah lahan petani tersebut, bisa dengan uang tunai atau cicilan ke lembaga/koperasi tersebut. Dengan demikian, proses jual beli lahan tersebut tidak akan menyebabkan alihfungsi lahan pertanian tetapi justru meningkatkan skala ekonomi usaha petani lainnya.

Hal ini sesuai dengan pendapat Dewi dan Rudianto (2013) desakan kebutuhan akan lahan yang dipergunakan untuk pembangunan begitu kuat, sementara luas lahan tidak akan bertambah atau terbatas, selama ini nilai lahan pertanian rendah bila dibandingkan dengan peruntukan lahan non pertanian yang mengakibatkan lahan pertanian secara terus menerus akan mengalami konversi lahan ke nonpertanian. Padahal lahan pertanian (sawah) selain mempunyai nilai ekonomi sebagai penyangga kebutuhan pangan, juga berfungsi ekologi seperti mengatur tata air.

Berbekal dari pengalaman kemitraan dengan petani di lapangan sebagai bagian dari peran dan fungsi dalam suatu penggerakan pemabangunan pertanian di dalam suatu desa tersebut. Bermitra dengan kelompok tani inilah yang menjadi pelaku utama di dalam suatu pembangunan pertanian di suatu pedesaan. Dalam hal ini kelompok tani adalah sebagai wadah untuk membangun suatu pembangunan pertanian seperti peran penyediaan suatu modal, penyediaan informasi, serta pemasaran produk-produk petani ke pasar. 


\subsection{Model pola kemitraan di kawasan KPH XIII Dolok Sanggul Kabupaten Humbang Hasundutan}

Untuk meningkatkan produktivitas lahan hutan melalui pengaturan pemanfaatan lahan. Pemanfaatan lahan hutan secara campuran antara tanaman hutan dan tanaman pangan, terutama dengan pemanfaatan jarak tanam dan umur pohon. Dalam pengelolaan hutan tanaman lestari, selalu harus tersedia tegakan siap tebang pada setiap tahun yang sekaligus merupakan lahan siap tanam. Lahan siap tanam ini merupakan areal yang potensial bagi tanaman pangan.

Peluang pemanfaatan lahan hutan untuk pertanian diharapkan dapat mengurangi atau mencegah pembukaan hutan sehingga lahan kering untuk perladangan dapat dikontrol. Pelaksanaan tanaman campuran tersebut diharapkan tersedia lahan untuk tanaman pangan bagi masyarakat dan fungsi hutan produksi tetap terjaga, serta pengelolaan hutan dalam rangka penyediaan bahan baku kayu bulat tetap terjamin. Agroforestry merupakan sistim penggunaan lahan dengan mengkombinasikan tanaman semusim dan tanaman pohon pada lahan yang sama. Salah satu bentuk agroforestry yaitu tanaman campuran antara jenis tanaman pangan seperti jagung dan kaliandra. Program agroforestry seperti tumpangsari sudah terlaksana dan ditambah nilai ekonomi dengan beternak lebah madu.

Berbekal pengalaman kemitraan dengan petani sebagai bagian dari peran dan fungsi dalam suatu penggerakan pembangunan pertanian di dalam suatu desa tersebut. Bermitra dengan kelompok tani inilah yang menjadi pelaku utama didalam suatu pembangunan pertanian di suatu pedesaan. Dalam hal ini kelompok tani adalah sebagai wadah untuk membangun suatu pembangunan pertanian seperti peran penyediaan suatu modal, penyediaan informasi, serta pemasaran produk-produk petani ke pasaran.

Pola kemitraan usaha yang perlu diterapkan dan harus dikembangkan di kawasan hutan KPH XIII Dolok Sanggul adalah kemitraan usaha agribisnis, yang diarahkan untuk menggantikan pola kemitraan yang selama ini masih berciri patronase. Dengan pola ini tidak dikenal lagi eksploitasi antar pelaku agribisnis dalam satu jaringan kegiatan agribisnis, baik secara terselubung, legal dan terbuka. Pola kemitraan usaha yang terbangun diharapkan dapat saling membutuhkan, memperkuat dan saling menguntungkan.

Pola kemitraan yang bernilai ekonomis dengan sistem agroforestry berbasis kopi dan jagung. Agroforestry kopi dan jagung sebagai salah satu komoditas utama petani hutan di KPH XIII Kabupten Humbang Hasundutan sekaligus menggembalakan lebah di areal perkebunan yang luas menguntungkan petani dan pembudidaya lebah. Karena keberadaan lebah membantu penyerbukan bunga mulai dari proses pencarian serbuk sari bunga oleh lebah hingga buah-buahan milik petani bisa berbuah sempurna. Sebaliknya, pemilik lebah mendapat sumber pakan untuk lebah penghasil madu. Masyarakat juga telah memungut madu lebah dari kawasan hutan desa, dengan program Hutan Desa ini akan mendukung KPH berbasis masyarakat.

\section{KESIMPULAN}

Peranan kelembagaan dan pola kemitraan berpengaruh dalam peningkatan kesejahteraan petani, namun mengingat kondisi akan kebutuhan individu pada kelompok tani yang semakin meningkat perlu adanya perbaikan dalam kemitraan dengan KPH XIII.

Model pola kemitraan yang dibutuhkan oleh masyarakat kelompok tani sekitar KPH XIII adalah pola kerjasama operasional agribisnis, yakni kelompok mitra menyediakan sarana produksi seperti lahan, sarana, dan tenaga kerja, sedangkan perusahaan hanya menyediakan modal, biaya, manajemen, dan pengadaan sarana produksi untuk mengusahakan atau membudidayakan suatu komoditas pertanian,salah satunya adalah budidaya lebah madu dengan tanaman utama kopi dan jagung

\section{SARAN}

Mendorong dan membibimbing petani agar mampu bekerjasama di bidang ekonomi ecara kelompok yang dapat meningkatkan pendapatan.

Untuk menunjang keberhasilan pembangunan hutan di KPH XIII harus berbasis kemitraan, perlu adanya keterlibatan berbagai pihak yang dilandasi oleh tujuan dan manfaat. Model pembangunan hutan dengan pola kemitraan PHBM (Pengelolaan Hutan Bersama Masyarakat), antara kelompok tani dengan KPH XIII yang tepat adalah model yang dibangun berdasar pada pengembangan dan penerapan tehnologi tepat guna serta pengembangan pola kemitraan agar terjadi transfer pengetahuan dan tehnologi pengusahaan hutan dan pengelolaan usaha dari mitra kepada masyarakat untuk meningkatkan kesejahteraan

\section{DAFTAR PUSTAKA}

A. Ficko, J. Roessiger, A. Boncina, 2016. Comparing heightage and height-diameter modelling approaches for estimating site productivity of natural uneven-aged forests. Forestry: An International Journal of Forest Research, Volume 89, Issue 4, August 2016, Pages 412421. DOI: 10.1093/forestry/cpw013

Afsana, K., Habte, D., Hatfield, J., Murphy, J., \& Neufeld, V. 2009. Partnership Assessment Toolkit. 1-25.Google Scholar. (diakses pada tanggal 28 September 2019)

Ahuja Vivek . 2011. Cyber Extension: A Convergence of ICT and Agricultural Development. Global Media Journal. Indian edittion / ISSN 2249 to 5835. Winter Issue/December 2011. Vol.2 (2).111-115

Anomsari, E. T. 2015. Community participation in community-based forest management (Case study in Karang Gayam Sub-District, Kebumen Regency). Natapraja, I(1), 75-91. 
Anonim. 2006. Undang-undang Nomor 16 Tahun 2006 tentang Sistem Penyuluhan Pertanian dan Kehutanan. Jakarta.

Arhamsyah. 2010. Pemanfaatan Biomassa Kayu sebagai Sumber Energi Terbarukan. Jurnal Riset Industri Hasil Hutan, 2 (1), 2010: 42- 48

Ary Widiyanto, 2015. Factors Influencing Farmers Decision Community-Based Forest Management Program, KPH Ciamis, West Java. DOI : 102086/ijfr.2019.6.1.1-16

Asfaw S., Di Battista, F., Lipper L. 2016. Agricultural Technology Adoption under Climate Change in the Sahel: Micro-evidence from Niger. Journal of African Economics 1-33

Awang, S, Afri, 2008 Panduan Pemberdayaan Lembaga Masyarakat Desa Hutan. Jakarta, Harapan Prima

Azadi, Filson, 2009. Comparative study of agricultural extension systems: A systemic view. Outlook on Agriculture 38(4), 337-347.

Badan Penyuluhan dan Pengembangan SDM Pertanian, 2010. Rencana Strategis Tahun 2010 - 2014. Badan Penyuluhan dan Pengembangan SDM Pertanian. Kementrian Pertanian. Jakarta.

Bizikova, L., M. Nijnik, and, T.K. Oravska, 2012 Sustaining Multifunctional Forestry through the Development of Social Capital And Promoting Participation. A Case of Multiethnic Mountain Communities. Small-scale Forestry 11, 301-319

Budimanta, Arif. 2004. Corporate Sosial Responsibility. Jakarta : Indonesia Center for Sustainable Development (ICSD). Jakarta

Bungin, Burhan. 2006. Sosiologi Komunikasi. Penerbit Prenada Media Group. Jakarta.

C. Leeuwis. 2010. Communication for Rural Innovation: Thinking Back On Agricultural Extension. Translation. Yogyakarta (ID): Canisius

Carletto, G., Savastano, S., Zezza, A. Fact or Artefact: The Impact of Measurement Errors on the Farm SizeProductivity Relationship. Journal of Development Economics. 103, 254-261

Christel C. Kern, Julia I. Burton, Patricia Raymond, Anthony W. D'Amato, William S. Keeton, illis Alejandro A. Royo, Michael B. Walters, Christopher R. Webster and John L., 2017. Challenges facing gap-based silviculture and possible solutions for mesic northern forests in North America Forestry (2017) 90 (1): 4-17.

Coillte, 2014. Coillte Submission for Forest Service Re: Consultation paper Forestry Programme 2014-2020 summary of proposed measures March 2014 draft proposals.

https://www.agriculture.gov.ie/media/migration/for estry/publicconsultation/submissionsreceived2014/ CoillteSubmissionforrestryProgramme150514.pdf (accessed on Mei 2019)

Dewi, W. S., Handayani, P., \& Sumani, 2008. Keragaman dan layanan ekologi makrofauna epigeik pada pertanaman wortel.Sains Tanah, 5(II), 113-120.
Don C. Bragg, 2017. The development of uneven-aged southern pine silviculture before the Crossett Experimental Forest (Arkansas, USA) Forestry (2017) 90 (3): 332-342.

Edoho, 2015. Entrepreneurship and Socioeconomic Development: Catalyzing African Transformation in the 21th Century. African Journal of Economic and Management Studies, 6(2), 127-147.

http://opac.lib.idu.ac.id/library_unhan/index.php?p=show_d etail\&id=6886 diakses tanggal 22 Oktober 2019

M. Ansori, 2012. Partnership Forest Management for the Prosperity of Community around Forest (Case of Community Based Forest Management Model in BKPH Parung Panjang, KPH Bogor). Dissertation. Bogor Agricultural University.

M. Butarbutar, 2007. Pelaksanaan Tanggungjawab Sosial HPH PT Teluk Nauli Membangun Kolaborasi Mitra Para Pihak dalam Strategi Konservasi Habitat Orangutan Sumatera di DAS Batang Toru. Kerjasama Dinas Kehutanan Provinsi Sumatera Utara, Departemen Kehutanan, Sumut

M. Kuncoro, 2004 Otonomi dan Pembangunan Daerah, Reformasi, Perencanaan, Strategi, dan eluang. Erlangga, Jakarta.

Mulyati R., 2005, Keanekaragaman Tanaman Pekarangan Dan Pemanfaatannya Di Desa, Pulau Wawoni- Sulawesi Tenggara, Jurnal Teknologi Lingkungan, Bppt, Vol 6, No http://digilib.bppt.go.id /ejurnal/index.php/JTL/article/view/425. (diakses pada tanggal 14 September 2019).

Nurma Kumala Dewi dan Iwan Rudiarto, 2013. Identifikasi Alih Fungsi Lahan Pertanian dan Kondisi Sosial Ekonomi Masyarakat Daerah Pinggiran di Kecamatan Gunungpati Kota Semarang, JURNAL WILAYAH DAN LINGKUNGANVolume 1 Nomor 2, Agustus 2013, 175-188

Peraturan Menteri Kehutanan RI, 2011.Peraturan Menteri Kehutanan Republik Indonesia NOMOR : P. 4/MenhutII/2011tentang Pedoman Reklamasi Hutan

Permatasari, Niken. 2003. Perspektif Pengembangan Ekonomi Lokal melalui Program Masyarakat Mandiri. Jurnal Sosioteknologi Edisi 13 Tahun 7, April 2008, $359-340$

PP No. 38/2007 tentang Pembagian Kewenangan Pemerintah Pusat, Pemerintah Daerah Provinsi dan Pemerintah Daerah Kabupaten/Kota.

S., Anantanyu, 2011. Kelembagan Petani : Peran dan Strategi Pengembangan Kapasitasnya, 7(2), 102- 109.

Sarintan E. Damanik, 2019. Pemberdayaan Masyarakat Desa Sekitar Kawasan Hutan, Uwais Inspirasi Indonesia, Jatim

Sarintan, E.Damanik, 2019. Perencanaan Pembangunan Kehutanan, Uwais Inspirasi Indonesia, Jatim

Sebatik Tengah Kabupaten Nunukan Provinsi Kalimantan Utara. Universitas Pertahanan Indonesia

Sumodiningrat, 2001. Kepemimpinan dan Pemberdayaan Ekonomi Rakyat, Faculty of Economic Inauguration Speech, Universitas Gadjah Mada. 
Supriyati, Muchjidin R., Kurnia S I., Tjetjep, Manurung, R., dan S. Rosmiyati, 2000. Studi Nilai Tukar Petani dan Nilai Tukar Komoditas Pertanian. Research report. Socio-Economic and Agricultural Policy Agricultural Department. Bogor.

Taariwuan, SA. Dkk, 2007. Analsis Marjin Pemasaran Kakao dan Implikasinya Terhadap Kesejahteraan MasyarakatPoso.

ww.//Pascasarjanaunsrat.com/home. (diakses pada tanggal 6 Oktober 2019)

Tambunan, 2003. Perkembangan Sektor Pertanian Di Indonesia (Beberapa Isu Penting), Ghalia Publisher, Jakarta.

Undang-Undang Nomor 32 Tahun 2004. Tentang Pemerintah Daerah

Undang-Undang Nomor. 9 Tahun 1995 tentang Usaha Kecil Masyarakat Indonesia.

Wahyudi, 2016. Interaksi Sosial Masyarakat Kawasan Perbatasan Di Desa Sungai Limau Kecamatan

World Bank 2014. World Development Indicators 2014. Washington, DC. http://data.worldbank.org/datacatalog/world-development-indicators.(diakses pada tanggal 14 September 2019) 